\title{
Could Local Residents Living Close to Wind Turbines Be Compensated for Damage to Their Health and Loss of Value of Their Homes?
}

\author{
L.B.A. Tigelaar \\ Assistant professor at the Department of Private law and Notarial law at the \\ University of Groningen, Groningen, The Netherlands \\ l.b.a.tigelaar@rug.nl
}

\begin{abstract}
Sustainability leads to the construction of more wind turbines on land. This installation is governed by rules of public law. Local residents living in the vicinity of wind turbines fear for their health and for the loss of value of their homes. This contribution examines whether and to what extent Dutch liability law offers the possibility to local residents to receive compensation for this damage. The Principles of European Tort Law are also addressed.
\end{abstract}

\section{Keywords}

Renewable Energy Directive - wind turbines - sustainability - Principles of European Tort Law - precautionairy principle - tort

The Renewable Energy Directive aims to promote the renewable forms of energy within the European Union. ${ }^{2}$ This revised Directive entered into force in

1 A Dutch version of this paper has been published in the journal Ars Aequi with the title: Kunnen omwonenden van windturbines eventuele gezondheidsschade en waardedaling van hun woning gecompenseerd krijgen? AA 2019, 2019/11. This English version incorporates two studies (Droës \& Koster 2019 and Daams \& Sijtsma 2019) that shed a different light on the loss of value of residents in the vicinity of wind turbines.

2 Consideration 2 of the Preamble of the Renewable Energy Directive (2018/2001/EU). The Directive has been based on Article 194 (1) (c) Treaty on the functioning of the European Union. 
December 2018, it replaces the Renewable Energy Directive of $2009^{3}$ and must be transposed before 30 June 2021. ${ }^{4}$ A binding overall Union target has been formulated in the Directive. The goal is that by 2030 the share of energy from renewable sources in the Union's gross final consumption of energy is at least $32 \% .^{5}$ Extracting energy from wind is an important instrument to reach this goal. This appears from various considerations and provisions of the Directive. Wind energy falls namely within the definition of 'energy from renewable sources, ${ }^{6}$ and the Directive contains a formula to calculate the electricity generated by wind power. ${ }^{7}$ In this calculation the directive distinguishes onshore wind power from offshore wind power.

The Directive obliges Member States to draft a national Renewable Energy Action Plan in order to meet the binding overall Union target of $32 \%{ }^{8}$ Each Member State was required to design such a plan by December 31, 2019 and to have it submitted to the European Commission by that date. ${ }^{9}$ The plan had to meet the eight broadly formulated requirements laid down in Regulation 2018/1999. The plans can be found on the website of the Commission. ${ }^{10}$ Most of the plans on the website have been based on the former Renewable Energy Directive. The national plan of the Netherlands shows that this Member State will try to obtain more energy from wind. ${ }^{11}$

Different parties have been involved in the Netherlands during the construction of wind turbines on land: governments, project developers, landowners and local residents. All kinds of regulations must be taken into account before and during the construction of wind turbines. Most of those regulations are part of public law. The construction of wind turbines possibly leads to health damage and a loss of value to the property. ${ }^{12}$ In this contribution I examine whether and to what extent liability law offers the possibility to local residents to receive compensation for this damage.

\footnotetext{
3 Renewable Energy Directive (2009/28/EC).

4 Article 36 (1) Renewable Energy Directive.

$5 \quad$ Article 3 (1) Renewable Energy Directive.

$6 \quad$ Article 2 (1) Renewable Energy Directive.

7 Consideration 32, Article 7 (2), and Annex II Renewable Energy Directive.

8 Consideration 8, 30 and Article 3 (2) of the Preamble of the Renewable Energy Directive.

9 Article 3 (1) Regulation on the Governance of the Energy Union and Climate Action (Regulation 2018/1999).

10 See https://ec.europa.eu/energy/topics/renewable-energy/national-renewable-energyaction-plans-2020_en?redir=1 (last consulted on 13 March 2020).

11 Nationaal Actieplan voor Energie uit hernieuwbare Bronnen, p. 31, 47, 59, 61 and 63.

12 See for a detailed discussion of these issues sections 3 and 4 .
} 
This contribution has been limited to opportunities offered by Dutch liability law. The Principles of European Tort Law are also addressed..$^{13}$ In this way the issue is not only considered from the Dutch perspective but also from a European perspective. Opportunities offered by administrative law will not be broadly examined, ${ }^{14}$ because this area of law does not offer a solution in the case of long-term damage like health damage. ${ }^{15}$ To answer the research question of this contribution I will pay attention to the Dutch procedures and regulations which must be complied with before the wind turbines can be constructed (second section). Thirdly, I will discuss whether wind turbines cause damage to human health and whether this can be compensated (third section). Fourthly, I will try to explore whether the construction of wind turbines affects the value of houses and whether this is eligible for compensation (fourth section). In the final section I will answer my research question.

\section{Dutch Procedure and Regulations}

\subsection{Procedure Prior to Construction}

In the Netherlands it is planned to construct wind turbines onshore and offshore on a fairly large scale. To construct onshore wind turbines you need a plot of land. This plot of land can be private or public property. A landowner himself, usually a farmer, can also take the initiative to construct wind turbines. ${ }^{16}$ In that case the landowner and developer coincide. A developer has several options if he does not own land and he or she wishes to exploit the opportunities offered by wind turbines. (1) He or she can buy the land from the landowner. According to Dutch law the developer will become the new land owner after the transfer. (2) He or she can also make an agreement with the landowner to use the land. In that situation the developer will compensate the landowner for using the land. However, such a contract has a disadvantage for the developer. According to Dutch law, the owner of the land will from that

\footnotetext{
13 See section 3 and 4 .

14 Although this will be briefly discussed in section 4.3.

15 Public law compensation for the construction of wind turbines has been discussed by J.W. van Zundert, 'Windmolens, wind- en zonneparken', Bouwrecht 2018/56.

16 See http://www.boerenbusiness.nl/artikel/10876863/gesubsidieerde-windmolensmaken-boeren-rijk (last consulted on 31 March 2020), https://www.nieuweoogst.nu/ nieuws/2018/12/10/de-strijd-van-vijf-boeren-voor-windmolens-in-zaltbommel (last consulted on 1 April 2020) and https://www.boerderij.nl/Home/Achtergrond/2018/4/Waarom -windparken-op-boerengrond-kansrijk-zijn-272717E/ (last consulted on 1 April 2020).
} 
point onwards become owner of the wind turbine based on accession. ${ }^{17}(3)$ The developer can also opt for a combination of those two possibilities. He or she can also conclude an agreement fortified with a residual right.

The developer must go through a public law procedure in order to obtain the required licences to construct the wind turbines. He has to apply to the competent authorities to obtain those permits. The Electricity Act 1998 contains a division of powers between the central Dutch government, provinces, and municipalities. ${ }^{18}$ The competent authority is to be determined on the basis of the capacity of the intended wind farm. Modern onshore wind turbines usually have a maximum power of 3 megawatts but less or more powerful turbines can be installed as well. ${ }^{19} \mathrm{~A}$ municipality is competent in case of a wind farm of 5 megawatts, a province is the competent authority in case of a wind farm of 5 to 100 megawatts and the central government is competent in the case of a wind farm of over more than 100 megawatts. This division of competences means that in most of the cases, the provinces are compentent to grant the permit for building onshore wind farms.

If the municipality is the competent authority, the internal division of competences is as follows. The municipal council has the power to determine the zoning plan. ${ }^{20}$ The Board of Major and Aldermen has the power to decide on the application for an environmental permit which is required for the construction of wind turbines. ${ }^{21} \mathrm{~A}$ similar division of competence applies in the case where the province is the competent authority. The provincial council is competent to determine the zoning plan, ${ }^{22}$ the provincial executive has the power to authorize the environmental permit. ${ }^{23}$ The central government is competent in the case of a large wind farm of over more than 100 megawatts. The Secretary of Economic Affairs and the Secretary of Infrastructure and Environment have the power to determine the zoning plan. ${ }^{24}$ The Board of Major and Aldermen of the municipality where the wind farm will be constructed are

\footnotetext{
17 Article 5:20 (1) Dutch Civil Code (Burgerlijk Wetboek).

18 Article ge and gb (1) under a Electricity Act 1998 jo. article 3.35 Act on Spatial Planning (Wet Ruimtelijke Ordening).

19 See https://www.windcentrale.nl/blog/hoeveel-energie-levert-een-windmolen-op/ (last consulted on 1 April 2020).

$20 \quad$ Article 3.1 Act on Spatial Planning.

21 Article 2.4 (1) Act on general provisions Environmental Law (Wet algemene bepalingen omgevingsrecht).

22 Article 3.26 Act on Spatial Planning.

23 Article 2.4 (2) Act on general provisions Environmental Law jo. article ge Electricity Act 1998.

24 Article 3.28 jo. article 1.1 (1) under a Act on Spatial Planning jo. article 1.1 (1) under a Electricity Act 1998.
} 
competent to decide on the application of the environmental permit. ${ }^{25}$ In some cases the Secretary of Housing and Spatial Planning has the authority to decide on this permit. ${ }^{26}$

\subsection{Regulations to Reduce Nuisance}

Different regulations aim to limit various nuisances like the noise and light glare of wind turbines. ${ }^{27}$ These regulations are important because an unlawful act in the meaning of article 6:162 Dutch Civil Code will be adopted less quickly where a developer has complied with these standards. Compliance with those administrative standards indicates lawful conduct. The municipality, province and the central government have to take those standards into account during the decision-making process regarding the construction of wind turbines.

A wind turbine may not generate more than 47 decibels of noise at the facade of houses during daytime, and 41 decibels at night. ${ }^{28}$ In order to get an idea of decibel scale, it is useful to know something about the background of this scale. The number of decibels indicates a sound level that is adjusted to our auditory sensitivity. An increase of only 3 decibels represents a doubling of the sound intensity. ${ }^{29}$ Examples of sounds that are 40 decibels are soft murmuring in a classroom and whistling of birds at sunrise. Examples of sounds of 50 decibels are: rain and humming of a refrigerator. ${ }^{30} \mathrm{~A}$ lot of noise is imperceptible to

25 Article 2.4 (1) Act on general provisions Environmental Law.

26 Art. 2.4 (3) and (4) Act on general provisions Environmental Law.

27 Namely the Decree on Environmental Management (Activiteitenbesluit Milieubeheer) and the Environmental Management Regulation (Activiteitenregeling Milieubeheer). For safety reasons, it is possible to set a minimum distance between the resident and the wind turbine (vNG, Rapport Milieuzonering nieuwe stijl 2019, p. 10).

28 Article 3.14a (1) Decree on Environmental Management. These values are long-term averages (Kennisbericht Geluid van Windturbines 2015, p. 1). The World Health Organization (wHO) recommends a strength of 45 decibels (wHO, Environmental Noise Guidelines for the European Region 2018, p. 77 and next). In practice, the sound of the wind turbines cumulates with other sounds. The following report addresses this accumulation of noise: Windplatform Verkenning Windenergie 2020, p. 23. This report can be found at: https:// www.windplatformgroningen.nl/wp-content/uploads/2020/o3/DRUKWERKWindplatform-rapport-DEF.pdf (last consulted on 5 May 2020).

29 See http://lichtbeeldgeluid.nl/geluid/akoestiek/wat-is-een-decibel/ (last consulted on 1 April 2020). The level on the decibel scale increases by 10 if the sound intensity becomes 10 times as high. Derived from https://www.natuurkunde.nl/opdrachten/1544/decibe lschaal-deel-2 (last consulted on 1 April 2020).

30 These examples have been derived from: http://home.planet.nl/ camino23/revalidatie/ dbwaarden.htm, https://www.cm.be/gezond-leven/lichaam/oren/decibelschaal and http://lichtbeeldgeluid.nl/geluid/akoestiek/hoe-hard-klinkt-een-decibel/ (last consulted on 1 April 2020). 
the human ear. The decibel value is negative in that case. ${ }^{31}$ That there is noise, is good to keep in mind in view of possible health damage which will be discussed in the next section. ${ }^{32}$

The material or coating layers of a wind turbine must meet the NENstandard, to avoid light glare. ${ }^{33}$ The developer has been obliged to provide the wind turbine with an automatic still-city facility that switches off the mill if the shadow falls on sensitive objects, like houses. ${ }^{34}$ This obligation exists if the distance between the wind turbine and the sensitive objects is less than 12 times the rotor diameter and cast shadow occurs more than 17 days per year for more than 20 minutes. ${ }^{35}$

\section{$3 \quad$ Do Wind Turbines Cause Health Damage?}

\subsection{Wind Turbines, Low-frequency Noise and Health Damage}

Various reports have appeared in the media about whether the presence of wind turbines leads to health damage to people. ${ }^{36}$ Most of the news items have

31 See https://www.natuurkunde.nl/opdrachten/1546/wat-betekent-dba (last consulted on 3 April 2020).

32 Section 3.

33 Article 3:14 (4) Decree on Environmental Management jo. article 3:13 and 1.2 Environmental Management Regulation.

34 Article 1.1 Decree on Environmental Management jo. article 1 Noise Abatement Act (Wet geluidshinder).

35 Article 3:14 (4) Decree on Environmental Management jo. article 3.12 Environmental Management Regulation. The distance must be determined on the basis of a point at axle height of the wind turbine to the facade of the sensitive object.

36 See: 'Wind turbines may trigger danger response in brain', The Telegraph 2015 can be found at: https://www.telegraph.co.uk/news/science/science-news/11736728/Windturbines-may-trigger-danger-response-in-brain.html (last consulted on 10 March 2020), 'Wind farm study finds 'no direct evidence' they affect health, The Guardian can be found at https://www.telegraph.co.uk/news/earth/energy/windpower/9653429/Windfarm-noise-does-harm-sleep-and-health-say-scientists.html, (last consulted on 10 March 2020) 'Wind farm noise does harm sleep and health, say scientists', The Telegraph 2012 can be found at: https://www.telegraph.co.uk/news/earth/energy/windpower/9653429/ Wind-farm-noise-does-harm-sleep-and-health-say-scientists.html (last consulted on 10 March 2020), 'Ziek van windmolens', Reformatorisch Dagblad 2018 via https://www.rd.nl/ meer-rd/wetenschap-techniek/ziek-van-windmolens-1.1490664, (last consulted on 3 April 2020), 'Professor: Windmolen maakt ziek', Dagblad van het Noorden 2018 (http:// platformstorm.nl/downloads/download/DVHN-20180518-Professor\%2oWindmolens\%2omaakt\%2oziek.pdf, last consulted on 3 April 2020), and 'Geen windmolens binnen 1500 meter van huizen' 2013 (https://eenvandaag.avrotros.nl/item/geen-windmolens -binnen-1500-meter-van-huizen/, last consulted on 3 April 2020). 
been based on the research of a Portuguese professor Mariana Alves-Pereira. ${ }^{37}$ She has done a case study on the impact of low-frequency noise from wind turbines on human health. ${ }^{38}$ The case is about a Portugese family with a farm. Four wind turbines of 2 megawatts were installed in 2006. As a result, the 12-year-old son appears to have developed abnormalities in his nerve condition. The father of the family seems to have developed cognitive disorders due to the presence of the turbines.

The relationship between the low-frequency noise from wind turbines and health problems can be explained as follows. There are two types of hair cells in the cochlea of the human ear. The inner hair cells respond to vibrations of sufficient strength and are responsible for our conscious 'hearing'. The outer hair cells are directly coupled to the tectorial membrane. They are stimulated by sounds at levels below those that can be heard. ${ }^{39}$ This infrasound thickens the area between the outer hair cells and the tectorial membrane so that the person in question becomes more sensitive to infrasound after a while. The effects of long-term exposure to infrasound may be: cardiovascular disease, respiratory problems and neurological problems.

In Dutch administrative case law judges have dealt several times with possible health damage caused by the construction of wind turbines. ${ }^{40}$ In some judgments this point is not addressed due to the poor substantiation of the

37 Mariana Alves-Pereira is doctor in Philosophy, Environmental Sciences. To consult a powerpoint presentation of this case: http://windsofustice.org.uk/wp-content/uploads/2014/ 08/Utrecht-2013-October\%2011.pdf and corresponding paper: https://www.researchgate .net/publication/290444707_Low_Frequency_Noise-Induced_Pathology_Contributions_ Provided_by_the_Portuguese_Wind_Turbine_Case, both last consulted on 3 April 2020. The Dutch family physician Sylvia van Manen points to this research in: 'Windmolens maken wel degelijk ziek', Medisch Contact 2018 (https://www.medischcontact.nl/nieuws/ laatste-nieuws/artikel/windmolens-maken-wel-degelijk-ziek.htm, last consulted on 3 April 2020. She also points in her contribution to the following publication: C.H. Hansen, C.J. Doolan \& K.L. Hansen, Wind farm noise: measurement, assessment, and control, Hoboken: Wiley Publishers 2017.

38 A case study is not large enough to be qualified as 'scientific'.

39 A.N. Salt \& T.E. Hullar, 'Responses of the ear to low frequency sounds, infrasound and wind trubines', Hearing Research 2010, pp. 15-17. Also discussed by Hansen, Doolan \& Hansen 2017, p. 459 and R. Tonin, 'A review of Wind Turbine-Generated Infrasound: Source, Measurement and Effect on Health', Acoustics Australia 2017.

40 ABRvS 29 May 2019, ECLI:NL:Rvs:2019:1781, ABRvS 19 September 2018, ECLI:NL:Rvs: 2018:3067, ABRvS 17 January 2018, ECLI:NL:RVS:2018:141, Rb. Rotterdam 2 July 2015, ECLI: NL:RвRоT:2015:4683, Rb. Oost-Brabant 23 April 2014, ECLI:NL:RBOBR:2014:2125, ECLI:NL: ввовR:2014:2124, ABRvS 19 June 2013, ECLI:NL:RvS:2013:CA3666; ABRvS 11 January 2012, ECLI:NL:RVS:2012:BV0565. These procedures have been started in response to granted licences. 
claim by the parties involved ${ }^{41}$ However, in other judgements extensive consideration is given to possible health damage. In two cases experts have drawn up test curves on the basis of which any nuisance of infrasound can be determined. ${ }^{42}$ The courts concluded in both cases that the increase in low-frequency noise as a result of the wind turbines is so limited that there can be no noise nuisance. ${ }^{43}$

In her considerations the highest administrative court of the Netherlands, the Dutch Council of State (Afdeling Bestuursrechtspraak van de Raad van State), focuses on reports of the Institute of Public Health and Environment (Rijksinstituut voor Volksgezondheid en Milieu (RIVM)). ${ }^{44}$ In contrast to the courts the Council of State specifically discusses the influence of infrasound on human health. The Council of State considers, based on the reports, that there is no scientific relation between health damage and low-frequency noise. ${ }^{45}$ The Council of State emphasizes that in individual cases the wind turbines can lead to sleep disturbance because their noise leads to annoyance. ${ }^{46}$ In this way the Council of State follows the current state of science: a significant link between low-frequency noise and health problems has not been established, but in individual cases the noise can lead to annoyance and that can have an effect on human health.

41 ABRvS 19 June 2013, ECLI:NL:RVS:2013:CA3666, consideration 12.

42 Rb. Rotterdam 2 July 2015, eCLI:NL:Rввот:2015:4683, consideration 10.3 and Rb. OostBrabant 23 April 2014, ECLI:NL:RвовR:2014:2125, ECLI:NL:RвовR:2014:2124, consideration 7.4.

43 Rb. Rotterdam 2 July 2015, ECLI:NL:Rввот:2015:4683, consideration 10.4 and Rb. OostBrabant 23 April 2014, ECLI:NL:RвовR:2014:2125, ECLI:NL:RвовR:2014:2124, consideration $7 \cdot 5$.

44 ABRvS 19 September 2018, ECLI:NL:Rvs:2018:3067, consideration 39, ABRvS 17 January 2018, ECLI:NL:RVS:2018:141, consideration 46; ABRvS 11 January 2012, ECLI:NL:RVs: 2012:BV0565, r.o. 2.11. The Council of State refers to the following reports: RIVM, Windturbines: invloed op de beleving en gezondheid van omwonenden 2013, RIVM, Kennisbericht Geluid van Windturbines 2015 en RIVM, Health effects related to wind turbine sound 2017.

45 ABRvS 29 Januari 2020, ECLI:NL:Rvs:2020:289, consideration 13.4, ABRvS 19 September 2018, ECLI:NL:RVS:2018:3067, consideration 39.1; ABRvS 17 January 2018, ECLI:NL:RVs: 2018:141, consderations 46.1 and 46.3 .

46 ABRvS 29 Januari 2020, ECLI:NL:RVS:2020:289, consideration 13.5, ABRvS 29 May 2019, ECLI:NL:RVS:2019:1781, consideration 100.2, ABRvS 19 september 2018, ECLI:NL:RVS:2018: 3067, consideration; ABRvS 17 January 2018, ECLI:NL:Rvs:2018:141, consideration 46.1. The Council of State bases this in particular on the RIVM-report of 2017. 


\subsection{Scientific Research on Wind Turbines and Health Damage}

There have not been many large-scale studies conducted on the effect of low-frequency noise from a wind turbine on human health. ${ }^{47}$ The conducted research shows no significant evidence that wind turbines have negative consequences for human health. ${ }^{48}$ For various reasons these studies may give a distorted picture. Firstly, the questionnaires in these studies had a low response rate. Furthermore, it is possible that health problems among the participants may not have revealed themselves, but will occur in the future. Finally, it may be that some participants have signed a Good Neighbour Agreement in which they have promised to be positive about the wind turbines. ${ }^{49}$ Such a promise can ensure that local residents do not dare to answer the survey at all or do not do so truthfully because they think they are bound by the Good Neighbour Agreement. Furthermore, various case studies exist which show that the noise from wind turbines does cause health problems to local residents. ${ }^{50}$ The results of these case studies seem to suggest that the noise leads to health problems for at least some of the local residents $(5 \%$ to $20 \%) .{ }^{51}$ The case studies and the aforementioned reasons are grounds for doubting the conclusion that wind turbines do not cause any health damage to local residents and show that there is scientific uncertainty.

\subsection{A Claim for Residents due to Health Damage in case of Scientific Uncertainty?}

The question arises as to whether residents have a civil law claim against the developer of wind turbines in the case of health damage caused by lowfrequency noise. The most obvious basis for such a claim is tort (Article 1:101 Principles of European Tort Law (PETL) and Article 6:162 Dutch Civil Code). Such a claim requires an unlawful act. This requirement will not be met easily

47 World Health Organization, Environmental Noise Guidelines for the European Region 2018, p. 85 .

48 RIVM, Health effects related to wind turbine sound 2017 and Hansen, Doolan \& Hansen 2017, p. 436 referring to pp. 43-50. Hansen, Doolan \& Hansen refer to studies which are conducted in Australia and Canada. Those are also discussed by Tonin 2017.

49 Hansen, Doolan \& Hansen 2017, p. 437.

50 Hansen, Doolan \& Hansen 2017, p. 437 refer to the following studies: M. Morris, Waterloo wind farm survey, Technical report, April 2012, P. Schneider, Cullerin Range wind farm survey, Technical report 2012 and P. Schneider, Cullerin Range wind farm survey: Followup survey. Technical report 2013. As part of these case studies, surveys were sent to local residents in a radius of 10 kilometers from the wind turbines. Furthermore, Hansen, Doolan \& Hansen 2017, p. 437 discuss research of: B. Thorne, Wind Farm Noise and Human Perception: A Review 2013.

$5^{1} \quad$ Hansen, Doolan \& Hansen 2017, p. 437 and 438. 
because the developer has complied with public law standards prior to the construction of the wind turbines. ${ }^{52} \mathrm{~A}$ tort or delict claim cannot nevertheless be excluded because the precautionary principle can be applied to this ground of fault-based liability. This precautionary principle can complement public law standards. Unlawful conduct on the part of a property developer may be presumed by the application of this principle despite the fact that standards under public law have been complied with. ${ }^{53}$

Various European contributions have been published on the precautionary priniciple in recent years. ${ }^{54}$ Just a few authors specifically address the precautionary principle within the doctrine of tort. ${ }^{55}$ The principle applies if it is uncertain whether an action or product can cause damage. The underlying idea of the precautionary principle is that in the case of a threat of serious damage, the lack of scientific certainty about the cause thereof cannot be invoked as a reason to postpone precautions. ${ }^{56}$ The precautionary principle therefore requires a proactive attitude that includes research and monitoring. ${ }^{57}$

Application of the precautionairy principle in the context of the requirements of Article 1:101 PETL and Article 6:162 Dutch Civil Code leads to two problems. The first problem relates to the requirement 'unlawful act'. Article 6:162 Dutch Civil Code defines this as follows: "An infringement of a right and an act or omission in violation of a statutory duty or of what, according to unwritten law, is customary in society". 58 The principles describe fault as follows: "A person is liable on the basis of fault for intentional or negligent violation of the required standard of conduct".59 As a result of this requirement, the question

52 The Dutch Public Law standards are discussed in the second section. Interesting to note is that the standards of the GGD (General Health Service) are more stringent than the Dutch Public Law standards. See Windplatform Verkenning Windenergie 2020, p. 25 (Report can be found at:https://www.windplatformgroningen.nl/wp-content/uploads/ 2020/03/DRUKWERK-Windplatform-rapport-DEF.pdf (last consulted on 5 May 2020)).

53 Going through the public law procedure does not indemnify the project developer from liability based on tort (HR 21 October 2005, ECLI:NL:HR:2005:AT8823 (Bouwvergunning Heemstede) and HR 10 March 1972, NJ 1972, 278 (Vermeulen/Lekkerkerker)).

54 E. Colarusso, 'Deconstruction and Reconstruction of a Relationship between the EU Preacautionairy Principle and Forward-Looking Information, European Business Law Review 2018, pp. 791-812, S. Lierman \& L. Veuchelen, 'Optimisation Approach of ALARA in Nuclear Practice', European Environmental Law Review 2006, pp. 98-107 and, J.L. da Cruz Villaca, 'The Precautionary Principle in EC Law', European Public Law 2004, pp. 369-405. For example: Lierman \& Veuchelen 2006.

56 Colarusso 2018, p. 794.

57 Lierman \& Veuchelen 2006, p. 105.

58 Article 6:162 (2) Dutch Civil Code.

59 Article 4:101 PETL. The required standard of conduct has been described subsequently in Article 4:102 (1) PETL. 
arises as to when and why an uncertain risk falls within in responsibility of the perpetrator. This requirement raises the question of when and why an uncertain risk falls within the sphere of responsibility of the person causing the damage.

The role of the precautionary principle in Dutch tort law has been discussed at a certain lenght in Dutch literature. According to De Jong in the context of the unlawfulness requirement, a precautionary obligation exists in relationships that are characterised by the presence of dependence and proximity between the person causing the uncertain risk and the person at risk. ${ }^{60}$ Dependency refers to the extent to which the uncertain risk subject is able to control and reduce the probability of unacceptable effects to an acceptable level without the help of the person causing the uncertain risk. ${ }^{61}$

The second problem is related to the conditio sine qua non ( $C S Q N)$ requirement. ${ }^{62}$ In the context of this requirement the question arises whether the act could have caused the damage. ${ }^{63}$ De Jong is reluctant to adopt an CSQN relationship if it is not certain that an action, method or product may cause damage. ${ }^{64}$ In view of undesirable expansion of liability law, De Jong believes caution should be exercised when transferring the uncertainty related to the causal relationship to the person causing the uncertain risk. ${ }^{65}$ Franken is more nuanced on this point. ${ }^{66}$ The financial consequences of accepting liability can be significant. That is the reason why in Franken's view in case of causality regarding a causal relationship between act and damage no compensation for the damage can be claimed under liability law, but only the other forms of reliefs offered by Dutch liability law, namely an injunction order or prohibition in the sense of Article 3:296 Dutch Civil Code.

The criteria of De Jong and the elaboration of Franken can be applied to wind turbines and the possible health damage of local residents. Uncertainty is exactly what occurs in this case. After all it is unknown whether lowfrequency noise from wind turbines causes health damage to local residents. A causal relationship between low-frequency noise and health damage has not

6o E.R. de Jong, 'Onzekere risico's en de verdeling van generieke causaliteitsonzekerheden vanuit twee paradigma's, Maandblad van Vermogensrecht 2018, p. 229.

61 De Jong 2018, p. 229.

62 This requirement has been described in Art.3:101 Principles of European Tort Law.

63 Lierman \& Veuchelen 2006, p. 105 have identified the same problem. The precautionary principle is difficult to reconcile with the required causal link within the concept of tort.

64 De Jong 2018, p. 234.

65 De Jong 2018, p. 233.

66 A.Ch.H. Franken, 'Het voorzorgsbeginsel in het aansprakelijkheidsrecht - een verkenning', Aansprakelijkeid, Verzekering \& Schade 2010, 25. 
been scientifically established. Application of the precautionairy principle, as discussed previous in this section, raises two issues regarding unlawfulness and causal relationship. Unlawfulness can be assumed because in the relationship between project developer and local resident there is a high degree of dependency. It is therefore hard for the resident to reduce the unacceptable effects of the wind turbine to an acceptable level without the support of the project developer. Local residents live close to the uncertain risk, namely the wind turbine and are exposed to the low-frequency noise. From the perspective of both 'dependence' and 'proximity', it can be assumed that the project developer has a precautionary obligation towards local residents. ${ }^{67}$

The required causal relationship makes it difficult for local residents to get compensation for possible health damage. In the light of Franken's view, local residents may well seek an injunction order or prohibition. ${ }^{68}$ This does not always have to include the actual prohibition of the construction of wind turbines, but can also include, for example, the imposition of a monitoring obligation..$^{69}$

Loss of Value of Houses after the Construction of Wind Turbines

\section{1}

\section{Scientific Research about the Loss of Value after the Construction of Wind Turbines}

Possible health damage is not the only reason for local residents to object against wind turbines. Their sound and cast shadow effect the quality of life. Thereby the presence of wind turbines may have an impact on the property value. $^{70} \mathrm{~A}$ relevant related question is therefore whether the construction of wind turbines has an effect on the value of the homes of local residents. The Dutch Tinbergen Instituut has carried out research into the influence of wind

67 Footnote 54 refers to European literature on the precautionary principle. At European level, this principle is less developed in the framework of tort, which can be linked to the low level of harmonisation of the doctrine.

68 See reference 66.

69 For a link between precautionary principle and monitoring obligation: Wetenschappelijke Raad voor Regeringsbeleid, Onzekere veiligheid. Verantwoordelijkheid rondom fysieke veiligheid, Amsterdam 2008, p. 147.

70 See various media reports about the loss of value: 'Property prices unaffected by windfarms, says CEBR', The Guardian 2014 can be found at: https://www.theguardian.com/ money/2014/mar/29/property-house-price-impact-wind-farms-turbines (last consulted on 10 March 2020), and 'Windfarms can reduce house prices by up to $12 \%$, says LSE', The Guardian 2014 can be found at: https://www.theguardian.com/money/2014/apr/o8/ windfarms-reduce-house-prices-compensation (last consulted on 10 March 2020). 
turbines on house prices. ${ }^{71}$ The construction of wind turbines in the vicinity of property has, depending on the distance between the wind turbine and the property, a decrease in value as a result of between $1,4 \%$ and $2.6 \% .{ }^{72}$ However, the Tinbergen Institute's research is based on a data set of housing transactions that took place between $1985^{-2011}$ and is therefore somewhat outdated. ${ }^{73}$ Since that period, the capacity of wind turbines has increased and they have a higher axis height. ${ }^{74}$ The research of the Tinbergen Institute has now been updated, the dataset has been extended to housing transactions up to and including 2019. ${ }^{75}$ This update shows an average decrease in value of houses in the vicinity of wind turbines of $2 \% .{ }^{76}$ Interestingly, the decline in value increases after 2011 to $3 \%{ }^{77}$ This seems to be related to the increased hight of wind turbines leading to more horizon pollution. ${ }^{78}$ Also another study has recently published on the planned installation of wind turbines in two northern provinces of the Netherlands and their effect on house prices. ${ }^{79}$ This study examined 20371 housing transactions that took place between $2008-2018 .{ }^{80} \mathrm{~A}$ clear picture in the data is that in places with a sight on the planned wind turbines residents are sold at lower prices. ${ }^{81}$

Studies on the impact of the construction of wind turbines on property prices have also been carried out in other countries. The results of these studies

$71 \quad$ M. I. Droës \& H.R.A. Koster, Renewable Energy and Negative Externalities: The Effect of Wind Turbines on House Prices 2014. Available at: https://papers.tinbergen.nl/14124.pdf (last consulted on 24 January 2020). This study has also been publised in the Journal of Urban Economics:: M.I. Dröes \& H.R.A. Koster, 'Renewable energy and negative externalities: The effect of wind turbines on house prices', Journal of Urban Economics 2016, p. 121-141.

72 Droës \& Koster 2016, p. 122.

73 Droës \& Koster 2016, p. 121.

74 S. Bond, S. Sims \& P. Dent, Towers, Turbines and Transmission Lines: Impacts on Property Value, Oxford: Wiley-Backwell 2013, p. 206.

75 M.I. Droës \& H.R.A Koster, Windturbines, zonneparken en woningprijzen 2019.

76 Droës \& Koster 2019, p. 33.

77 Droës \& Koster 2019, p. 33.

78 Droës \& Koster 2019, p. 25 and 33.

79 M. Daams \& F. Sijtsma, Windparken en Woningprijzen in Groningen en Drenthe: Rapportage in opdracht van RTV Noord en RTV Drenthe, Groningen: Urban and Regional Studies Institute 2019. This study can be found at: https://www.rug.nl/research/portal/files/ 109497616/191125_1812_Rapport_RUG_2019_Windparken_en_Woningprijzen_4_.pdf (last consulted on 7 May 2020). This study has limitations because the construction of wind turbines has not yet been realised (Daams \& Sijtsma 2019, p. 12).

$80 \quad$ Daams \& Sijtsma 2019, p. 12.

81 Daams \& Sijtsma 2019, p. 12. 
differ. Sometimes loss of value is assumed, ${ }^{82}$ sometimes it is not. ${ }^{83}$ Given the different outcomes of these studies, there is some uncertainty with regard to this damage. However, the most recent Dutch studies do show a decline in value, but the exact level of decrease is still uncertain. ${ }^{84}$

\subsection{Analysis of Dutch Case Law Concerning Loss of Property Value after the Construction of Wind Turbines}

Cases delivered by a court in response to the valuation of property based on the Real Estate Valuation Act (Wet Waardering Onroerende Zaken) give an interesting perspective on the question whether the construction of wind turbines causes a loss of value. ${ }^{85}$ The Board of Major and Aldermen decide the value of the property and on the basis of this value they determine the property tax. The construction of wind turbines or any plans for construction are often reason for property owners who live in the vicinity of the wind turbines to object against this decision and to start a judicial procedure. ${ }^{86}$ According to the owners, the actual value of their property is lower than what the municipality has determined. This is because wind turbines are in the vicinity of the property or will be constructed in the near future. Dooper and Bosch have analysed this case law. ${ }^{87}$ Their research has been commissioned by the Ministry of Economic Affairs, Agriculture and Innovation. They conclude that it is not possible to conclude on the basis of the analysed case law whether nearby wind turbines have an effect on the value of the property or not. According to them this requires research into actual, realised property transactions. ${ }^{88}$

82 Y. Sunak \& R. Madlener, 'The impact of wind farm visibility on property values: A spatial difference-in-difference analysis', Energy Economics 2016, p. 90 and S. Gibbons, 'Gone with the Wind: Valuing the visual impacts of wind turbines through house prices', Journal of Environmental Economics and Management 2015, p. 193 and 194.

83 Signorelli 2014, p. 118 and 119, C. Lang, J.J. Opaleuch \& G. Sfinarolaki, 'The windy city: Property value impacts of wind turbines in an urban setting', Energy Economics 2014, p. 420 and 421, Bond, Sims \& Dent 2013, p. 238, J. Carter, The Effect of Wind Farms on Residential Property Values in Lee County, Illinois, Illinois State University 2011, p. 25 and 26 and B. Hoen, R. Wiser, P. Cappers, M. Thayer \& B. Sethi, 'Wind Energy Facilities and Residential Properties: The Effect of Proximity and View on Sales Prices',Journal of Real Estate Research 2011, p. 308.

84 Droës \& Koster 2019 and Daams \& Sijtsma 2019.

85 Article 17 Real Estate Valuation Act (Wet Waardering Onroerende Zaken).

86 See case law cited in references 91 and next.

87 J. Dooper \& G. Bosch, De invloed van windturbines op de waarde van onroerend goed, Anayse van jurisprudentie 2012. Can be found on: https://www.rvo.nl/sites/default/files/ 2013/o9/Bosch\%2oen\%2oVan\%2oRijn\%2ojurisprudentie\%2oeffect\%2owindtur bines\%20op\%2oWOZ_o.pdf (last consulted on 30 January 2020). 
The question is what an analysis of these cases concerning the value of property in the vicinity of wind turbines shows exactly. Such an analysis reflects the judicial review of the value of property located in the vicinity of wind turbines, value determined by a municipal officer on behalf of the Board of the municipality. Courts review this value in the context of the following provision:

"The value is determined on the basis of the value to be attributed to the immovable property if the full and unencumbured ownership thereof could be transferred and the transferee could use the property in its state and in full extent." 89

A judge must imagine a fictitious situation as a result of this provision. $\mathrm{He}$ must check whether the property is valued at the value that the transferee will pay in the event of a transaction. He uses reference objects such as houses nearby. ${ }^{90}$ The published case law in which the court applies this test thus approaches reality and is therefore important.

The case law that Dooper and Bosch have analyzed covers the period from May 2003 to May 2011. ${ }^{91}$ Courts have subsequently issued more judgments that

89 Article 17 (2) Real Estate Valuation Act. Dutch translation: "De waarde wordt bepaald op de waarde die aan de onroerende zaak dient te worden toegekend, indien de volle en onbezwaarde eigendom daarvan zou kunnen worden overgedragen en de verkrijger de zaak in de staat waarin die zich bevindt, onmiddellijk en in volle omvang in gebruik zou kunnen nemen".

$90 \quad$ For example: Rechtbank Noord-Nederland 1o May 2017, ECLI:NL:RBNNE:2017:1793, r.o. 4.1; Hof Arnhem-Leeuwarden 18 May 2016, ECLI:NL:G HARL:2016:3822, r.o. 4.8; Hof ArnhemLeeuwarden 26 August 2014: ECLI:NL:G HARL:2014:6694, r.o. 4.3 e.v and Rechtbank Middelburg 19 January, ECLI:NL:RBMID:2010:BMo736.

91 They have examined the following 19 cases: Gerechtshof Amsterdam 12 May 2011, ECLI:NL:GHAMS:2011:BQ4864; Gerechtshof Den Haag 14 April 2010, ECLI:NL:GHSGR: 2010:BM2564; Rechtbank Middelburg 19 January, ECLI:NL:RBMID:2010:BMo736; Gerechtshof Den Haag 5 January 2010: ECLI:NL:GHSGR:2010:BL4239; Rechtbank Alkmaar 24 December 2009, ECLI:NL:RBALK:2009:BK9429; Hof Arnhem-Leeuwarden 1 December 2009, ECLI:NL:G HARN:2009:BK7031; Hof Arnhem-Leeuwarden 24 November 2009, ECLI: NL:GHARN:2009:BK6118; Rechtbank Arnhem 16 July 2009, ECLI:NL:RBARN:2009:BJ3019; Gerechtshof Amsterdam 6 March 2009, ECLI:NL:GHAMS:2009:BH5974; Gerechtshof Leeuwarden 17 August 2007, ECLI:NL:G HLEE:2007:BB2096; Gerechtshof Leeuwarden 17 August 2007, ECLI:NL:GHLEE:2007:BB2097; Rechtbank Middelburg 16 April 2007, ECLI: NL:RBMID:2007:BB5448; Rechtbank Leeuwarden 8 March 2007, ECLI:NL:RBLEE:2007: BA0431; Rechtbank Middelburg 23 January 2007, ECLI:NL:RBMID:2007:BA4768; Rechtbank Zwolle-Lelystad 26 October 2006, ECLI:NL:RBZLY:20o6:AZ1572; Rechtbank Groningen 20 January 2006, ECLI:NL:RBGRO:2006:AX6528; Rechtbank Leeuwarden 18 January 2006, ECLI:NL:RBLEE:2006:AVoo76; Gerechtshof Leeuwarden 18 July 2003, ECLI:NL: 
have been published. ${ }^{92}$ Courts and courts of appeal generally assume a decrease in value due to the presence of the wind turbines. ${ }^{93}$ In these cases they do so because the municipal officer did not take sufficient account of the presence of the wind turbines when determining the woz-value. In case law of a more recent date, courts tend to accept a fall in value less often. ${ }^{94}$ This is because in these cases the municipal officer, when determining the woz-value, did have an eye for the fact that wind turbines are located in the vicinity of the property. This shows a development regarding the fact that in the published case law from May 2003 to the present municipality officers have taken account

GHLEE:2003:AI0841; Gerechtshof Leeuwarden 7 May 2003, ECLI:NL:GHLEE:2003:AF9o19 (Dooper \& Bosch 2012, p. 12-30).

92 Gerechtshof Arnhem-Leeuwarden 19 December 2017, ECLI:NL:G HARL:2017:11131; Gerechtshof Arnhem-Leeuwarden 7 November 2017, ECLI:NL:GHARL:2017:9618; Rechtbank Noord-Nederland 10 May 2017, ECLI:NL:RBNNE:2017:1793; Gerechtshof Arnhem-Leeuwarden 25 October 2016, ECLI:NL:GHARL:2016:8540; Gerechtshof Arnhem-Leeuwarden 17 August 2016, ECLI:NL:G HARL:2016:6587; Gerechtshof Arnhem-Leeuwarden 5 April 2016, ECLI:NL:GHARL:2016:2677; Hof Arnhem-Leeuwarden 18 May 2016, ECLI:NL:GHARL: 2016:3822; Hof Arnhem-Leeuwarden 17 March 2015, ECLI:NL:GHARL:2015:2294; Hof Arnhem-Leeuwarden 26 August 2014: ECLI:NL:GHARL:2014:6694. Two cases that were also issued in the period May 2003- May 2011, but were not included in the analysis by Dooper and Bosch, are: Rechtbank Breda 13 August 2008, ECLI:NL:RBBRE:2008:2637;Rech tbank Haarlem 10 October 2006, ECLI:NL:RBHAA:2006:AY9808.

93 See Gerechtshof Arnhem-Leeuwarden 25 October 2016, ECLI:NL:GHARL:2016:8540; Gerechtshof Arnhem-Leeuwarden 17 August 2016, ECLI:NL:GHARL:2016:6587; Gerechtshof Amsterdam 12 May 2011, ECLI:NL:G HAMs:2011:BQ4864; Gerechtshof Den Haag 14 April 2010, ECLI:NL::G HSG R:2010:BM2564; Gerechtshof Den Haag 5January 2010: ECLI:NL: GHSGR:2010:BL4239; Rechtbank Arnhem 16 July 2009, ECLI:NL:RBARN:2009:BJ3019; Gerechtshof Amsterdam 6 March 2009, ECLI:NL:GHAMS:2009:BH5974; Rechtbank Breda 13 August 2008, ECLI:NL:RBBRE:2008:2637; Gerechtshof Leeuwarden 17 August 2007, ECLI: NL:GHLEE:2007:BB2096; Gerechtshof Leeuwarden 17 August 2007, ECLI:NL:G HLEE:2007: BB2097; Rechtbank Zwolle-Lelystad 26 October 2006, ECLI:NL:RBZLY:2006:AZ1572; Rechtbank Haarlem 10 October 2006, ECLI:NL:RB HAA:2006:AY9808; Rechtbank Leeuwarden 18 januari 2006, ECLI:NL:RBLEE:2006:AVoo76; Gerechtshof Leeuwarden 18 July 2003, ECLI:NL:G HLEE:2003:AIo841; Gerechtshof Leeuwarden 7 May 2003, ECLI:NL:G HLEE:2003: AFgorg.

94 Gerechtshof Arnhem-Leeuwarden 19 December 2017, ECLI:NL:G HARL:2017:11131; Gerechtshof Arnhem-Leeuwarden 7 November 2017, ECLI:NL:GHARL:2017:9618; Rechtbank Noord-Nederland 10 May 2017, ECLI:NL:RBNNE:2017:1793; Gerechtshof Arnhem-Leeuwarden 5 April 2016, ecli:NL:G HARL:2016:2677; Hof Arnhem-Leeuwarden 26 August 2014: ECLI:NL:GHARL:2014:6694; Rechtbank Middelburg 19 January, ECLI:NL:RBMID:2010: BMo736; Rechtbank Alkmaar 24 December 2009, ECLI:NL:RBALK:20o9:BK9429; Hof Arnhem-Leeuwarden 1 December 2009, ECLI:NL:G HARN:2009:BK7031; Rechtbank Leeu warden 8 March 2007, ECLI:NL:RBLEE:2007:BA0431; Rechtbank Middelburg 23 January 2007, ECLI:NL:RBMID:2007:BA4768; Rechtbank Groningen 20 January 2006, ECLI:NL: RBGRO:2006:AX6528. 
of the presence of wind turbines when determining the woz-value. The analysed case law indicates that the presence of wind turbines apparently influences the value of the property in a negative way. This analysis thus confirms the outcome of the Dutch studies discussed in section 4.1.

\subsection{A Claim for Local Residents due to a Fall in Value?}

The decrease in value of the houses of local residents is probably due to the nuisance of the wind turbines in the form of noise, cast shadow and landscape pollution. Local residents can try to prevent or recover the decrease in value on the basis of Art.1:101 Principles of European Tort Law or Article 6:162 BW of the Dutch Civil Code. This claim against the project developer has a chance of success, but there are some obstacles. ${ }^{95} \mathrm{~A}$ successful claim requires an imputable wrongful act, damage and a causal relationship between the act and the damage. ${ }^{96}$ As with damage to health, it is difficult for local residents to prove the causal relationship between the construction and the decrease in value of the property. ${ }^{97}$ Furthermore, it is hard to determine the extent of the damage. To prove this an analysis of housing transactions is needed.

These obstacles are grounds to take the loss of value into account when making decisions about the construction of wind turbines. This already happens in most cases, as shown in the NLVow-report commissioned by the Ministry of Economic Affairs. ${ }^{98}$ Examples of arrangements made with local residents to compensate for a loss of value can be found in the attachment of this report. ${ }^{99}$ Sometimes there is an arrangement that allows local residents to benefit from the yield of the wind turbines. ${ }^{100}$ There is also a compensation based on public law available if the decrease in value is higher than $2 \% .{ }^{101} \mathrm{How}$ this compensation relates to compensation based on tort should be further examined. Apparently, project developers and government authorities are trying to accommodate local residents with these regulations.

95 The actual effect of wind turbines on the property depends partly on the answer to the question whether wind turbines cause damage to health.

96 Also the protective norm criterium must be met.

97 See section 3.3.

98 A. Koers \& R. Rietveld, Omgevingsparticipatie bijwindenergie op land 2017 (to be found on: http://nlvow.nl/wp-content/uploads/2018/o3/NLVOW-Handboek-Toolkit-Omgevingspar ticipatie.pdf, last consulted on 3 April 2020).

$99 \quad$ Koers \& Rietveld 2017, p. 99, 104 and 108.

$100 \quad$ Koers \& Rietveld 2017, p. 90 and 132.

101 Article 6.2 (2) Act on Spatial Planning. In future this must be 5\% according to Article 15.7

(1) Environmental Act (Omgevingswet). 
Several Member States will construct wind turbines on a relatively large scale in order to meet the objective of the Renewable Energy Directive. This may have a negative side effect for local residents. In this contribution I have examined, based on a case study focusing on Dutch tort law, whether and to what extent liability law offers local residents the possibility to receive compensation for possible health damage and decrease in value of property, which has arisen by the construction of wind turbines in the vicinity of houses.

Research seems to indicate that low-frequency noise from wind turbines can cause annoyance that can lead to health problems. A direct link between low-frequency noise from wind turbines and physical health problems has not (yet) been demonstrated. With this state of affairs there is uncertainty in scientific research. This makes it impossible to actually receive compensation based on tort for health damage as a local resident because the causal relationship between the damage and the presence of the wind turbine is uncertain. The project developer is subject to a precautionary obligation in respect of local residents within the framework of the unlawfulness requirement. This does, however makes it possible for local residents to demand, for example, that the wind turbine be placed at a greater distance from their homes; that any damage be objectively monitored and that more research be carried out into the effect on health of low-frequency noise from wind turbines. These rights of local residents can be taken into account by the administrative body when granting the necessary permits to the project developer for the construction of the wind turbines. From a civil law point of view it is desirable that the project developer, the administrative body and the local resident make agreements about monitoring and further research prior to the construction of the wind turbines.

The loss of value of the property as a result of the construction of the wind turbines is partly related to the potential health damage. If it is certain that wind turbines do not pose a health risk, a property owner will find the presence of the wind turbines probably less objectionable. This does not alter the fact that the decrease in the value of the property can also be regarded as a given caused inter alia by landscape pollution. A claim based on tort can be successful but there are several obstacles to overcome. Especially, the causal relationship between the construction of the wind turbines and the decrease in value of the property, the level of decrease and the availability of compensation based on public law are issues that need to be kept in mind. But, getting energy from wind is not for free. 